\title{
Analysis of Patients in the Geriatric Population Between Ages 80 and 100 Years Admitted to and Treated in a Thoracic Surgery Clinic: 5 years' Experience
}

\author{
Göğüs Cerrahisi Kliniğine Yatırılarak Tedavi Edilen Geriatrik Popülasyondaki 80-100 Yaș Arası \\ Hastaların Analizi; Beș Yıllık Deneyim
}

\author{
İbrahim Ethem Özsoy, Mehmet Akif Tezcan \\ Sağllk Bilimleri Üniversitesi, Kayseri Sağlık Uygulama ve Araştırma Merkezi, Göğüs Cerrahisi Anabilim Dal, Kayseri, Türkiye
}

\begin{abstract}
Aim: The aim of this study was to determine the profiles of the patients aged 80 years and over admitted to the thoracic surgery clinic, their reasons for admission, the diagnostic and therapeutic approaches adopted for these patients, and the factors affecting their morbidity and mortality rates.
\end{abstract}

Material and Method: Patient data retrieved from the hospital information management system were retrospectively analyzed. The patients were evaluated in terms of demographic information, reason for hospitalization, clinical findings, concomitant chronic diseases, diagnostic and treatment methods used, intensive care need, total hospitalization duration, and outcome.

Results: In the 5-year period between 2013 and 2018, 422 patients aged $\geq 80$ years were hospitalized and treated in the thoracic surgery clinic. The average age of the patients was 84.7 years (80-99 years). Pleural effusion and thoracic trauma were among the most common reasons for admission. The average length of stay in the hospital was 4.4 days. Forty-seven patients were treated in the intensive care unit, and overall 17 patients (4\%) were dead.

Conclusion: Our population continues to age, which means that we will more frequently encounter patients $\geq 80$ years of age in thoracic surgery in the near future. Our experience with these patients, their profiles, their reasons for admission, and the diagnostic and therapeutic approaches adopted for these patients, and the factors affecting their morbidity and mortality will serve as a guide to the thoracic surgery clinics that will frequently encounter geriatric patients.

Key words: geriatrics; octogenarian; thoracic surgery

\section{ÖZET}

Amaç: Gögüs Cerrahisi Kliniğine kabul edilen 80 yaș üzerindeki hastaların profilleri, bașvuru nedenleri, tanı ve tedavi yaklașımları ile morbidite ve mortaliteyi etkileyen faktörler ve oranlarının belirlenmesi amaçlanmıștır.

Materyal ve Metot: Hastane bilgi yönetim sisteminden hastalara ait datalar retrospektif olarak incelendi. Hastalar demografik bulguları, yatıș nedeni, klinik bulgular, eșlik eden kronik rahatsızlıklar, uygulanan tanı ve tedavi yöntemi, yoğun bakım ihtiyacı, toplam yatıș süresi ve sonuçlar açısından değerlendirildi.

Bulgular: 2013-2018 arasındaki beș yıllık sürede Göğüs Cerrahi kliniğine 80 yașından büyük 422 hasta yatırılarak tedavi edildi. Hastaların yaș ortalaması 84,7 (80-99 yaș) idi. Plevral efüzyon ve toraks travmasına bağlı nedenler en sık etiyolojik faktörlerdi. Ortalama hastanede yatıș süresi 4,4 gündü. Kırk yedi hasta yoğun bakımda takip edildi, 17 (\%4) hasta kaybedildi.

Sonuç: Nüfusumuz yașlanmaya devam etmekte ve 80 yașından büyük hastalarla Göğüs Cerrahisinde daha sık karșılașmaktayız. Bu hastaların profilleri, bașvuru nedenleri, tanı ve tedavi yaklașımları ile morbidite ve mortaliteyi etkileyen faktörleri bilmemiz Gögüs Cerrahisi kliniklerine yol gösterici olacaktır.

Anahtar kelimeler: geriatri; oktogenaryan; göğüs cerrahisi

IIetișim/Contact: İbrahim Ethem Özsoy, Sağlık Bilimleri Üniversitesi, Kayseri Sağlık Uygulama ve Araştırma Merkezi, Göğüs Cerrahisi Anabilim Dall, Kayseri, Türkiye • Tel: 05068552998 • E-mail: ibrahimethem.ozsoy@sbu.edu.tr • Geliș/Received: 26.09.2019 • Kabul/Accepted: 30.05 .2020 ORCID: İbrahim Ethem Özsoy, 0000-0003-2722-5309 • Mehmet Akif Tezcan, 0000-0002-2642-187X 


\section{Introduction}

Population projections by the Turkish Statistics Institute show that between 2018 and 2080 the life expectancy at birth will increase in Turkey, and that our population will continue to age. The proportion of the population aged 65 years and over, defined as the elderly population, has been projected to reach $10.2 \%$ by $2023,16.3 \%$ by $2040,22.6 \%$ by 2060 , and $25.6 \%$ by $2080^{1}$. The proportion of the population in the octogenarian and nonagenarian groups has been estimated to be $1.77 \%$ by $2018,1.93 \%$ by $2023,3.83 \%$ by 2040 , $7.01 \%$ by 2060 , and $9.27 \%$ by $2080^{2}$.

The increasing elderly population also suggests that we, at Thoracic Surgery Clinics, will encounter more patients over 80 years of age than previously. It is well known that compared to young patients, elderly patients are admitted to Thoracic Surgery Clinics with more complex problems, are subjected to more radiological and laboratory procedures, and stay longer in the clinic due to the presence of other conditions. In patients over 80 years old, many factors, such as physiological changes in the cardiac, respiratory, and other systems, comorbid conditions, cognitive and psychological states, nutritional status, and family and social support can affect the treatment process ${ }^{3}$.

The aim of this study was to determine the profiles of the patients $\geq 80$ years of age admitted to the thoracic surgery clinic: their reasons for admission, the diagnostic and therapeutic approaches adopted for these patients, and the factors affecting their morbidity and mortality rates.

\section{Material and Methods}

The study was approved by the Local Ethics Committee (Date, 07.11.2018/No: 2018/551) and was conducted in accordance with the principles of the Declaration of Helsinki.

The city hospital is situated has a population of 1.377 .000 , and around $22.000(1.60 \%)$ of its population is $>80$ years old. Our hospital operates as a tertiary medical center. Patient data retrieved from the hospital information management system were retrospectively analyzed. All patients over 80 years old who were hospitalized in our clinic were included in the study. Notably, patients under 80 years of age were excluded from the study. The patients were evaluated in two groups: "80-84 years" and " 85 and older". The patients were evaluated in terms of demographic findings, reason for hospitalization, clinical findings, concomitant chronic diseases, diagnostic and treatment methods used, intensive care need, total hospitalization duration, and outcome.

The coding and statistical analyses of the data were performed using the IBM SPSS 22 package program. The numerical values of the patients' information were expressed as mean \pm standard deviation (mean \pm SD) and categorical values as median \pm minimum-maximum (median \pm min-max). The Mann-Whitney $U$ test and Student's $t$ test were used for analysis of continuous variables with non-parametric and parametric values, respectively. Comparisons of categorical values were assessed with Chi-square test or Fisher's exact test; $\mathrm{p}<0.05$ was considered statistically significant.

\section{Results}

In the 5-year period between 1 January 2013 and 31 December 2017,422 patients $\geq 80$ years old were hospitalized and treated in the thoracic surgery clinic. The average age of the patients was 84.7 years (range $80-$ 99 years). The patients were evaluated in two groups: " $80-84$ years" and " 85 and older". Of these patients, 221 (52.4\%) were between 80 and 84 years old, and $201(47.6 \%)$ between 85 and older. Of all patients, $153(36.3 \%)$ were female and 269 (63.7\%) were male. Three hundred and fifty of the patients $(82.9 \%)$ were admitted to the emergency department. Pleural effusion and thoracic trauma were among the most common reasons for admission.

Forty-seven patients were followed up in the intensive care unit, and 17 (4\%) patients died. Transfer to intensive care unit were more frequent in " 85 and older" group $(p=0.12)$, but not statistically significant. Inhospital mortality was similar in both age groups. Five patients were died due to malignant pleural effusion, 5 patients were died due to flail chest, 3 patients were died due to diffuse lung contusion, 2 patients were died due to lung cancer, one patient was died due to secondary spontaneous pneumothorax, and one patient was died due to hemoptysis.

The presence of comorbidities had similar and high rates in both groups. Three hundred nine (73.2\%) of the patients had cardiovascular diseases (hypertension, coronary artery disease, congestive heart failure and atrial fibrillation), 142 (33.6\%) of the patients had chronic obstructive pulmonary disease, 177 (41.9\%) of the patients had diabetes mellitus, 18 (4.3\%) of the patients had chronic renal failure, and 38 (9\%) of the patients had cerebrovascular disease. Chronic obstructive pulmonary 
disease, diabetes mellitus, and hypertension were the most common comorbidities in both groups $(\mathrm{p}>0.05)$. The incidence of congestive heart failure was higher in the "85 and older" group than in the " $80-84$ years" group $(\mathrm{p}=0.006)$. Invasive mechanical ventilation was performed in 11 patients in the "80-84 years" group and in 10 patients in the " 85 and older" group $(\mathrm{p}=0.382)$.

The average length of stay in the hospital was 4.4 days. The mean length of stay was $4.37 \pm 4.51$ days in the " $80-84$ years" group, $4.29 \pm 4.52$ days in the " 85 and older" group. Nine patients length of stay for more than 15 days were " $80-84$ years" group and 7 patients were "85 and older" group (five patients had empyema and 11 patients had pleural effusion). The length of stay was not significantly different between age groups. The number of multiple hospitalized patients were 32 (7.6\%). Table 1 shows the patients' demographic data, diagnosis, and treatment approaches.

\section{Discussion}

Proper diagnosis, treatment, and follow-up of chronic diseases such as cardiovascular and pulmonary diseases and diabetes mellitus, improvements in the fields of nutrition, vaccination and hygiene, and, most

Table 1. Patients' demographic data, diagnosis and treatment approaches

\begin{tabular}{|c|c|c|}
\hline & $\mathrm{n}$ & Procedure/0peration \\
\hline \multicolumn{3}{|l|}{ Characteristics } \\
\hline Age (average) & $84.7(80-99)$ & \\
\hline Age $80-84$ & $221(52.4 \%)$ & \\
\hline Age 85-89 & $151(35.8 \%)$ & \\
\hline Age 90-94 & $41(9.7 \%)$ & \\
\hline Age 95-99 & $9(2.1 \%)$ & \\
\hline \multicolumn{3}{|l|}{ Gender } \\
\hline Female & $153(36.3 \%)$ & \\
\hline Male & $269(63.7 \%)$ & \\
\hline \multicolumn{3}{|l|}{ Etiologies } \\
\hline Pleural effusion & $180(42.7 \%)$ & ThT, CT, TT, CP, VATS \\
\hline Malignant pleural effusion & 74 & \\
\hline Congestive heart failure & 61 & \\
\hline Parapneumonic effusion & 21 & \\
\hline Other (cirrhosis, tuberculous pleural effusion, undiagnosed) & 24 & \\
\hline Thoracic trauma & $144(34.1 \%)$ & \\
\hline Rib fracture, singular & 83 & $\mathrm{IB}, \mathrm{A}, \mathrm{RP}$ \\
\hline Rib fracture, multiple & 29 & $\mathrm{IB}, \mathrm{A}, \mathrm{RP}$ \\
\hline Sternum fracture & 3 & $\mathrm{~A}, \mathrm{RP}$ \\
\hline Lung contusion & 17 & AT, RP \\
\hline Pnx, Htx & 12 & TT \\
\hline Lung and mediastinal mass & $29(6.9 \%)$ & TTNB \\
\hline SSP & $21(5 \%)$ & TT, CP, VATS \\
\hline Malignancies (Breast, gastric, etc.) & $19(4.5 \%)$ & $\mathrm{CPC}$ \\
\hline Chronic renal failure & $18(4.3 \%)$ & AVF, PDC \\
\hline Lung cancer & $6(1.4 \%)$ & L,WR \\
\hline Hemoptysis & $3(0.7 \%)$ & FOB \\
\hline Chylothorax & $1(0.2 \%)$ & $\pi$ \\
\hline FBA & $1(0.2 \%)$ & $\mathrm{RB}$ \\
\hline Duration of hospitalization, day & $4.4(1-37)$ & \\
\hline Intensive care unit & $47(11.1 \%)$ & \\
\hline Mechanical ventilator & $21(5 \%)$ & \\
\hline Exitus & $17(4 \%)$ & \\
\hline
\end{tabular}

A, analgesia; AT, antibiotic therapy; AVF, arteriovenous fistula; CP, chemical pleurodesis; CPC, chemotherapy port catheter; CT, catheter thoracostomy; FBA, tracheobronchial foreign body aspiration; FOB, fiberoptic bronchoscopy; IB, intercostal blockage; L, lobectomy; PDC, permanent dialysis catheter; Pnx; Htx, traumatic pneumothorax; haemothorax; RB, rigid bronchoscopy; RP, respiratory physiotherapy; SSP, secondary spontaneous pneumothorax; ; ThT, therapeutic thoracentesis; TT, tube thoracostomy; TTNB, transthoracic needle biopsy; WR, wedge resection. 
importantly, advances in health care services have drastically increased the life expectancy in developed and developing countries. The increase in the elderly population in our society and, in particular, in the population $\geq 80$ years old can actually be regarded as an important achievement. In parallel with this increase, the hospitalized elderly population will grow and healthcare professionals in all of the medical branches will have to be prepared for this patient group.

Pleural effusion and thoracic trauma were among the most common reasons for admission of patients $\geq 80$ years old to the thoracic surgery clinic, and $\sim 77 \%$ of the patients were admitted to our clinic for these two reasons. Because pleural effusion usually develops as a complication of various diseases, it can be difficult to clearly determine its incidence. Pleural effusion may develop in $25 \%-50 \%$ of patients with congestive heart failure, pneumonia, or malignant disease ${ }^{3}$. If we would like to give a rate for the causes of pleural effusions in Turkey, then it is necessary for us to combine the case rates reported in different publications. Malignant pleural effusion is $\sim 41 \%$, parapneumonic pleural effusion $16 \%$, tuberculous pleural effusion $15 \%$, and heart failure $20 \%{ }^{4-6}$.

Pleural effusions due to congestive heart failure are the type of effusion where a consultation from thoracic surgeons is most frequently requested. In Turkey, heart failure among patients with pleural fluids is between $6 \%$ and $38 \%$, and it is in general $20 \%{ }^{4-6}$. These patients respond very well to properly -and carefully-regulated medical treatment. If they fail to respond to the treatment being administered and are symptomatic, then it is appropriate to evacuate the fluid with the aid of thoracentesis or catheter thoracostomy. The rate of heart failure among elderly patients with pleural effusion being admitted to our clinic is $\sim 34 \%$. There is a kind of rationale in that appropriate treatment is given to patients $\geq 80$ years of age with pleural effusion who are admitted to the emergency department with symptoms and have been hospitalized by the Chest Diseases and Cardiology Clinics. As the patients are symptomatic, they are hospitalized as a result of the consultations that are requested from thoracic surgery, and some or all of their fluids are drained in order to provide relief, which in turn shows a high incidence of heart failure among our patients with pleural effusion.

When elderly patients with cirrhosis accompanied by ascites have pleural effusion, they constitute the most challenging patient group for whom we should be constantly striving to improve. The underlying liver disease in these patients should be treated appropriately (salt restriction, diuretic, nutrition, etc.). According to our clinical experiences, tube or catheter thoracostomy should not be immediately used to treat these patients. Otherwise, daily fluid drainage increases to a very large quantity, such as $4000-5000 \mathrm{ml}$, and serious protein and electrolyte disturbances develop as drainage continues at these levels for days, which further worsens the clinical status of the elderly and vulnerable patient. If possible, intervene with medical treatment only, and if possible, drainage of pleural fluid under sterile conditions should be ensured. Therefore, the most appropriate approach is intermittent evacuation thoracentesis instead of tube thoracostomy for these patients.

Trauma leads to serious consequences in all age groups, and to even more serious problems in patients $\geq 80$ years of age. Comorbid conditions -such as diabetes mellitus, chronic obstructive pulmonary disease, hypertension, coronary artery disease, and cerebrovascular diseasefrequently accompany the trauma for which these individuals are admitted. The most common mechanism of injury in the elderly population is falling -it is an important cause of morbidity and mortality- followed by motor vehicle accidents. Falls at this age are mostly in the form of falling to the ground while standing and may relate to accompanying cardiovascular or nervous system pathologies. Rib fractures and extremity fractures are frequently seen in elderly patients who are prone to falling because osteoporotic changes are present in most of these patients. Hemothorax is common in many patients as they use antiaggregant (antiplatelet) drugs such as acetylsalicylic acid or clopidogrel ${ }^{7-10}$. Elderly patients have a fragile and rigid chest wall; therefore, they are more likely to experience rib fracture. The number of broken ribs in elderly patients was found to correspond to high morbidity $^{11}$. About $78 \%$ of the patients $\geq 80$ years old who were hospitalized due to thoracic trauma had rib fractures. Although we implemented proper and effective analgesia, respiratory physiotherapy, and embolism prophylaxis, five patients with concomitant chronic obstructive pulmonary disease and extremity fracture died. A short stay in the intensive care unit will reduce the morbidity and mortality rates of patients with rib fracture and chronic disease restricting the respiratory reserve.

Secondary spontaneous pneumothorax (SSP), which is usually seen in advanced ages and develops secondary to underlying lung disease, is the collection of air in the pleural space without traumatic or iatrogenic causes. The most common cause of SSP development is $\mathrm{COPD}^{12}$. It 
has been reported that every pneumothorax attack in patients with COPD may increase the mortality fourfold $^{13}$. An effective means of preventing recurrences is pleurodesis. If pleurodesis is not performed, $40 \%-50 \%$ of patients will have the pneumothorax recur ${ }^{14}$. Twentyone patients were hospitalized with a diagnosis of SSP. We established a tube thoracostomy in all of them. In 17 patients, the tube thoracostomy was sufficient and we performed chemical pleurodesis with talc in all of these patients. Four patients with prolonged and continued air leakage underwent video-assisted thoracoscopic surgery (VATS). We performed talc pleurodesis after bullectomy during the operation. At 6 months of follow-up, only two patients experienced recurrence and pleurodesis was repeated in them.

The number of elderly patients diagnosed with lung cancer increases in parallel with the growth in our elderly population and is projected to rise further in the future. For this reason, the choice of treatment for elderly patients with non-small cell lung cancer becomes even more important. Chronological age alone should not be a contraindication for treatment in any patient. In the elderly patient population $>75$ years of age, the type of surgical intervention selected did not result in a significant difference in survival between those undergoing wedge resection and segmentectomy, described as limited resection, and those undergoing lobectomy. It can be said that VATS and limited resection would be more preferable and more useful techniques for treating high-risk elderly patients ${ }^{15-18}$. Of the six patients, one underwent lobectomy and five underwent wedge resection. Two of our patients with good preoperative pulmonary function had atelectasis in the postoperative period. There were no other complications. We can safely perform lung resection, when required, by better carrying out the preoperative evaluation, regardless of chronological age.

Our population continues to age, which means that we will more frequently encounter patients $\geq 80$ years of age in thoracic surgery in the near future. Our experience with these patients, their profiles, their reasons for admission, the diagnostic and therapeutic approaches used for them, and the factors affecting their morbidity and mortality will serve as a guide to the thoracic surgery clinics that will frequently encounter geriatric patients.

Our study has some limitations. Our study was based on retrospective, and involved a single centre. Because causes of hospitalization may vary according to the characteristics of hospitals, it is not possible to generalize our results.

\section{References}

1. Population Projections, 2018-2080. Turkish Statistical Institude Newsletter Ankara;http://www.tuik.gov.tr/PreHaberBultenleri. do?id=30567;2018 [accessed 21.02.18].

2. Temel İstatistikler. Nüfus ve Demografi, http://www.tuik.gov. tr/UstMenu.do?metod=temelist;2020 [accessed 10.07.20].

3. Light RW, Rogers JT, Moyers JP, Lee YC, Rodriguez RM, Alford WC Jr, et al. Prevalence and clinical course of pleural effusions at 30 days after coronary artery and cardiac surgery. Am J Respir Crit Care Med 2002;166(12):1567-71.

4. Gümüş A, Çınarka H, Karataş M. Elevated pleural copeptin levels can distinguish to exudate from transudates. Tuberk Toraks 2014;62(4):267-72.

5. Şenyiğit A, Işık B, Coşkunsel N. 305 Plevral Efüzyonlu Vakanın İncelenmesi. Solunum Hastalıkları 1996;7(3):395-404.

6. Gönlügür TE, Gönlügür U 454 Plevral Efüzyonun Retrospektif Analizi. İnönü Üniversitesi Tip Fakültesi Derg 2007;14(1):21-5.

7. Mandavia D, Newton K. Geriatric trauma. Emerg Med Clin North Am 1998;16:257-74.

8. Roudsari BS, Ebel BE, Corso PS. The acute medical care costs of fall-related injuries among the US older adults. Injury 2005;36:1316-22.

9. Kong LB, Lekawa M, Navarro RA, McGrath J, Cohen M, Margulies DR, et al. Pedestrian-motor vehicle trauma: an analysis of injury profiles by age. J Am Coll Surg 1996;182:17-23.

10. Pyke OJ Jr, Rubano JA, Vosswinkel JA. Admission of elderly blunt thoracic trauma patients directly to the intensive care unit improves outcomes. J Surg Res 2017;219:334-40.

11. Barnea $Y$, Kashtan $H$, Skornick Y. Isolated rib fractures in elderly patients: mortality and morbidity. Can J Surg 2002;45(1):43-6.

12. Çelik B, Nadir A, Şahin E. Nüks spontan pnömotrakslı olgularda risk faktörleri, klinik ve radyolojik değerlendirme. Türk Göğüs Kalp Damar Cer Derg 2008;16:107-12.

13. Williams-Johnson J, Williams EW, Hart N. Simultaneous spontaneous bilateral pneumothoraces in an asthmatic. West Indian Med J 2008;57:508-10.

14. Kuzucu A, Soysal O, Ulutaş H. Optimal timing for surgical treatment to prevent recurrens of spontaneous pneumothorax. Surg Today 2006;36:865-8.

15. Spaggiari L, Scanagatta P. Surgery of non-small cell lung, cancer in the elderly. Curr Opin Oncol 2007;19:84-91.

16. Mery CM, Pappas AN, Bueno R, Colson YL, Linden P, Sugarbaker DJ, et al. Similar long-term survival of elderly patients with non-small cell lung cancer treated with lobectomy or wedge resection within the surveillance, epidemiology, and end results database. Chest 2005;128:237-45.

17. Jaklitsch MT, Bueno R, Swanson SJ. New surgical options for elderly lung cancer patients. Chest 1999;116:480-5.

18. Dell'Amore A, Monteverde M, Martucci N, Sanna S, Caroli G, Stella F, et al. Early and long-term results of pulmonary resection for non-small-cell lung cancer in patients over 75 years of age: a multi-institutional study. Interact Cardiovasc Thorac Surg 2013;16(3):250-6. 